\title{
The Value of CPA in Exploration of the New Pattern of Social Governance and Its Improvement*
}

\author{
Qin Wei \\ Hubei University of Police \\ Wuhan, China 430034
}

\begin{abstract}
Establishment and development of citizen police academies is of great significance for building a harmonious relationship between the police and the public. At present, China has established citizen police academies in some areas. However, problems such as insufficient activity funds, lack of targeted curriculum, defect of recruitment for training participants, and lack of organization work for students in the latter stage hinder its development. Therefore, by strengthening theoretical research, this paper proposes to establish a system that combines social donations and financial appropriations, and take measures such as online registration system and student communication mechanism for later stage, to improve and promote the development of citizen police academies.
\end{abstract}

Keywords-citizens police academy; social governance; policecitizen cooperation

\section{INTRODUCTION}

In the report of the 19th National Congress of the Communist Party of China on strengthening and innovating social governance, $\mathrm{Xi}$ Jinping proposed to build a social governance pattern of co-building, cp-governance, and sharing. To strengthen the construction of social governance system, it is necessary to strengthen the social governance system with social coordination, public participation, and legal guarantee system, and improve the level of socialization, legalization, intellectualization and specialization of social governance. Therefore, we should strengthen the construction of community governance system, promote the focus of social governance to grassroots, give play to the role of social organizations, and achieve a benign interaction among government's governance, social regulation and residents' selfgovernance. China's social governance has always emphasized "adhering to centering on the people", innovating the mechanism and methods of mass work, and looking for ways to improve risk prevention and control mechanisms of public security management departments, as well as the way to enhance citizens' ability to control public security risks, and citizen police academy is one of the innovative ways to combine the two.

*[Fund Project] Education Science Planning Project of Hubei Province, "CPA Mode Value and Construction in the Perspective of Public Security Social Management Innovation" (2013B158).

\section{The ORIGIN AND PracticAl VALUE Of CITIZEN POLICE ACADEMY}

\section{A. Origin}

The establishment of citizen police academy (hereinafter referred to as "CPA") is a very popular practice in Western countries to ease the relationship between the police and the public. In Western countries, citizen police academies are schools or training classes run by local police stations for citizens who have registered and passed examination, with the purpose of educating citizens to let them know about police stations' work, policing policies, laws and regulations, the criminal justice system, and ways to reduce crime, so that citizens can have a deeper understanding of police and policing work.

The citizen police academy system originated in the United Kingdom. In 1977 in Exeter, UK, the Mounted Police in Devon and Cornwall established a famous project called "Police Night School", which aimed to familiarize citizens with the nature, organizational structure and operation mode of English police's work, thereby better strengthening the communication between the police and the public. In 1985, the Orlando Police Department in Florida established a citizen police academy where students could choose to take part in a patrol program or complete a compressed weapon training course. The subjects covered in the course included police management, drugs and gun safety. The ultimate goal of the Orlando Citizen Police Academy was to strengthen citizens' understanding of police department and community, thereby reducing crime, which was considered a new type of law enforcement tool for law-enforcing departments. The practice of the Orlando Police Department has been promoted. As of 2015 , more than $65 \%$ of police agencies in the United States had set up citizen police academies. "Shanghai Citizen Police Academy" in China was established on March 20, 2010. Nearly 100 Expo volunteers entered the police camp and became the first batch of students of the citizen police academy, whose initial aim was to build a harmonious relationship between the police and the public, and promote community policing strategies. Relevant persons say that citizen police academy provides a new operational platform for communication between the police and the public, creates a set of new mechanism for police-public communication and police-community cooperation, provides community police officers and citizens with active interaction opportunities to 
share relevant ideas and information, eliminates doubts and misunderstandings, and ultimately makes the relationship between the police and the public more harmonious, greatly mobilizing the participation and support of citizens. Judging from the practical effects of the above-mentioned citizen police academies in various countries, the public has more opportunities to enter the police camp, personally experience the work of the police, familiarize with the police's discipline and laws, understand the structure and nature of the police work, eliminate the misunderstanding of the police, and strengthen the understanding of the police work, which effectively eases the tension between the police and the public, improves citizens' self-defense skills, and deepens the cooperation between the police and the public.

\section{B. The Value of Exploring a New Pattern of Social Governance}

1) The development of citizen police academies is conducive to establishing a good relationship between the police and the public: Robert Peel, British Home Secretary, once said: "Always keeping in close contact with the public means following the historical tradition that 'the police are the public, and the public is the police'." If ordinary citizens have the opportunity to participate in and experience the work of front-line police through citizens polices academies, clearly understand the substance of police work, personally understand the hardship and many challenges in the work of the police, and thus understand, trust and support for the work of the police, it is conducive to eliminating prejudice against the police. In 1985, the first US citizen police academy was established in Orlando, Florida. "Some citizens have signed up for police academy to find fault with the police, but after 13 weeks of courses, $80 \%$ of the students formed a positive view." Because they can see the pressure of the front-line police in work and their impact of the entire judicial system on the police and the general public, and they can enjoy the opportunity to interact with the community police, share relevant ideas and information, eliminate doubts and misunderstandings, and finally make the relationship between the police and the public more harmonious. Therefore, citizen police academy is a catalyst for close relationship between the police and the public, and its development is conducive to promoting communication and exchanges between the police and the public, so that the public maintains long-term cooperation with the police.

2) The promotion of citizen police academy is conducive to the training of police volunteers: Due to the limited police force and unlimited public force, a lot of police work requires the participation of the public to achieve good results. Therefore, many police activities require the participation of volunteers, especially volunteers who have certain knowledge and understanding of police work. Through the study at the citizen police academy, more ordinary citizens fully understand the basic knowledge of policing work, which closes the distance between the police and the public, strengthens the citizens' trust and understanding of the police.
When policing work requires volunteers, students of police academies are more willing to support and participate in community policing activities. A survey of CPA students has been conducted in the United States, and many of the surveyed devoted themselves to voluntary activities of crime prevention and security programs sponsored by the police after graduation.

\section{Status QuO OF CPA CONSTRUCTION IN CHINA}

In recent years, due to various reasons, the relationship between the police and the public in our country is tensive, which is not conducive to cooperation between the police and the public. Therefore, China's public security organs are working hard to implement and build a variety of police public communication platforms, and trying to eliminate misunderstandings between the police and the public. As a result, the citizen police academy system begins to receive attention.

\section{A. Development Status of citizen police Academies in China}

The citizen police system of our country appeared late. With the continuous implementation of community policing in China, citizen police academy, as an important measure to build harmonious relationship between the police and the public, has been gradually valued by public security organs. In 2010, the citizen police academy system began to be implemented in China. In 2010, Shanghai Police College took the opportunity of the World Expo and established the first citizen police academy in China. The academy integrates the teaching resources of Shanghai Police College and the education and training strength of Shanghai Public Security Bureau, and establishes a three-level citizen police academy system covering "city, district, and police station". According to statistics, the citizen police academy in Shanghai has received good social response and expanded influence since its opening, and the number of students has been rising, from more than 4,000 in 2011 to more than 6,000 in the first half of 2013. On November 26, 2011, Beijing Citizen Police Academy was formally established, and the first batch of 600 students from different fields of society learned about the prevention and control of public security disasters, social group prevention and related policing work, and preference was given to those who obtained the course-completion certificate in the recruitment of civilian service, auxiliary police and security guards of Beijing Public Security Bureau. The opening of the citizen police academy has achieved good social effects in China and played a positive role in public security organs' efforts to win public support. In addition, other provinces have gradually established local citizen police academies. For example, in 2015, Tongxiang City Public Security Bureau of Zhejiang Province firstly established a citizen police academy in the province. In 2016, Shishi City established the first citizen police academy in Fujian Province and officially opened to the public.

\section{B. Characteristics of the Establishment and Development of the Current Citizen Police Academy System in China}

1) Uneven distribution of regions: According to the actual situation, there are not many provinces and cities that have 
established citizen police academy in China, which are mainly distributed in Beijing, Shanghai, Hangzhou and some coastal cities. For example, on March 13, 2016, the citizen police academy in Shangcheng District, Hangzhou City, Zhejiang Province was opened for classes, and at the first stage, it carried out targeted training for precaution of phone fraud according to the current crime hotspots. Nearly 900 Ping'an Volunteers from 121 financial bank outlets in Shangcheng District received the training in the class of the "citizens" police academy". Anti-fraud expert of the "citizens police academy" combined with typical phone fraud cases to introduce the "three ones" method for precautions, namely "one more question in the lobby, more attention by security guards, and one more warning at the window", which further enhanced financial bank staff's precaution consciousness and response to phone fraud. In the past month, the financial bank staff successfully prevented 6 phone fraud cases with used the precaution knowledge learned in the "citizens' police academy", stopping loss of RMB 1132800. It is understood that the purpose of opening the "citizens police academy" in Shangcheng District was to escort 2016 China G20 Summit in Hangzhou, do a good job in pre-job training for Ping'an Volunteers in Shangcheng District, and make them better serve as "information staff, lookout patrol, observer, and rescuers". This fully proved that the "citizens' police academy" had full social value and potential for exploring the new pattern of social governance. However, the reality also shows that in addition to CPA exploration and practice in large cities and developed coastal cities, a larger part of the central and western provinces and second-tier and third-tier cities have not yet established such an academy, which may be related to the limitations of local funds or the thinking of organization managers. The funds for establishing a citizen police academy come from financial support, and the financial development of each place is inconsistent. The economies in Beijing, Shanghai and coastal cities are relatively developed, while the economies of western and central cities are relatively backward. Therefore, it has restricted the development of citizen police academies in each place to a certain extent.

2) The content of courses is dominated by traditional security precautions: According to the current course arrangement of citizen police academies in China, it mainly focuses on personal safety, self-defense, police camp experience, fire escape, self-rescue in emergency, police dogs and police dog assistance, visit to 110 command center of public security bureaus, use of police equipment and gun, firing practice, visit to detention houses, understanding of the management system of prison, and network security knowledge. According to the practice, although these courses well reflect the characteristics of policing work, they lack specific law enforcement procedures for police departments, such as traffic enforcement, investigation procedures, patrol procedures, criminal investigation procedures, laws and procedures of search and seizure, etc., so that the citizens are not active to participate, and the effect is not ideal. Therefore, how to make the courses of citizen police academies meet the needs of the public needs further exploration.

3) Citizens police academy students are mainly recruited from specific groups of people: In the early stage of the construction of citizen police academy, due to its low social influence, students were mainly recruited from specific groups, through cooperation with various administrative agencies, enterprises and social organizations at all levels, with the combination of individual voluntariness and unit recommendation. Although such recruitment method guarantees the student source of citizen police academy to a certain extent, it is not conducive to improving the enthusiasm of participants and the universality of participants.

\section{IMPROVING THE PATH SELECTION OF CPA DEVELOPMENT IN CHINA}

In order to better promote and develop citizen police academy in China, further efforts in the following aspects need to be made:

\section{A. Strengthening the Theoretical Property and Practicalness of the Citizen Police Academy System}

Strengthening the theoretical and practical research of the citizen police academy system will help local public security organs better understand the role of citizen police academy and promote the construction of citizen police academies in each place. Citizen police academy is a new thing that sprang up in the 1970s and 1980s. There is not much research on it in China's academic circles. By searching in CNKI, as of 2015, there had only been 17 papers themed on citizen police academy in China, which shows that the public security organs in China have not yet fully understood the citizen police system. The establishment and operation of citizen police academy is mainly carried out under the leadership and promotion of local public security organs. If the public security organs cannot attach importance to the construction of citizens 'police academy, the system cannot be quickly promoted. Therefore, strengthening the relevant research on the citizen police academy system and drawing on some successful experiences of Western countries can help the public security organs quickly understand the positive role of the citizen police academy in promoting the society, thus promoting the establishment of citizen police academies in various places.

\section{B. The Curriculum Setting Should Focus on the Needs of the Public}

Whether the design of curriculum content is reasonable directly affects the public's participating enthusiasm. Therefore, curriculum should be rationally designed according to the characteristics of public security work and public needs, to actively look for hot spots that can attract public attention. In Western countries, the curriculum content mainly includes several aspects: 1. Policies and procedures of police departments; 2. Traffic enforcement and investigation; 3. Patrol procedures; 4. Criminal investigation; 5. Laws and procedures for search and seizure; 6. Education of resisting drug abuse; 7. Maintaining community public security services, 
responsibilities of police departments, public relations, special tactical rescue teams, and response to domestic violence.

From the perspective of curriculum design and arrangement abroad, curriculum arrangement of citizen police academies is highly targeted and practical. Through citizen police academy, ordinary citizens can learn about police enforcement procedures in addition to self-defense courses. The police enforcement procedure is a matter of concern to ordinary citizens, because whether the police strictly enforce the law in accordance with procedures directly affects whether the legitimate rights and interests of citizens can be effectively protected. Helping citizens understand the police enforcement procedures can encourage them to actively cooperate with police enforcement activities and strengthen supervision of police enforcement activities at the same time. Therefore, citizen police academies across China must be targeted in curriculum design, in addition to the curriculum on citizens' safety education, curriculum design should also be carried out around various law enforcement authorities and procedures of the police, which is conducive to inspiring the participating enthusiasm of ordinary citizens. Therefore, in the future, the training content design of CPA in China should include both citizen etiquette, citizen self-prevention skills, laws and regulations, and also provide highly targeted courses according to different groups. In addition to grassroots police officers or police experts, members of instructor team who come to class can also be strictly selected legal elites, including senior legal experts and well-known lawyers with social influence. In addition to regular skill training for legal and police literacy, students of "citizens police academy" also enjoy student benefits such as student points, student insurance, and green channels; students who provide important information that is judged to have valuable clues will receive material rewards. Upon graduation, the students will also receive a coursecompletion certificate.

\section{Properly Solving the Funds for the Activities of Citizen Police Academy}

According to the actual situation, in order to ensure the participation of ordinary citizens in citizen police academy, ordinary citizens do not need to pay any fees for participating in police academy training, and all expenses are borne by the sponsor of citizen police academy, the public security organ, whose funding sources mainly rely on local financial allocations. Due to the different levels of economic development in various places, it may affect the establishment and development of citizen police academies. Therefore, the way to expand funding sources for activities is to ensure that citizen police academies can last for a long time. For the activity funds of citizen police academies in China, the following two approaches can be used: the one is to pay part of the expenses by financial department, and the other is to pay another part of the expenses by social sponsorship. In order to ensure that these social sponsorship funds are not randomly diverted, an effective monitoring mechanism should be established.

\section{Citizens Police Academies Should Recruit Students Mainly as Volunteers}

Currently, citizen police academies in China recruit members with a combination of individual voluntariness and unit recommendation. In practice, unit recommendation is more dominant. However, according to the trend of foreign development, the self-registered students have greater enthusiasm for citizen police academy and more urgent understanding of the police work, who are more likely to become partners and volunteers of the police work. Therefore, when recruiting students, foreign citizen police academies directly publish announcements for recruiting students on the Internet. Taking the United States as an example, in current practice, the registration and review of citizen police academies in various places are conducted online. Around October each year, local police stations publish announcements for recruiting students of citizen police academy on the Internet to invite interested citizens to participate in training. People directly fill in the form online to register, and those who pass the review are informed of the training time. The public obtains a lot of public information on the Internet. Therefore, when recruiting citizen police academy students, local public security organs may consider publishing announcements on the website of local public security bureaus so that volunteer citizens can register directly on the Internet.

\section{E. Public Security Organs Establish a Corresponding Relationship with Students}

Citizens' police academies enable residents to understand the organizational culture, core values, and overall process of department operation of their local law enforcement agencies. Citizen police academies provide citizens with a chance to closely get in touch with the police, understand the tasks, policies and regulations that the police must abide by, and let them better understand the profession of police. At the same time, they can also publicize some requirements for maintaining the security order of communities, as well as the social ethics, laws and regulations, etc. that the public needs to abide by. Most "students" who "graduate" from citizen police academies may become advocates and supporters of police policy implementation, which will lay a good foundation for building trust between the police and the public. Therefore, public security organs must establish a good correspondence with students in so as to enable citizen police academies to achieve good communication results and promote the harmonious development of relations between the police and the public. The purpose of citizen police academy is to create opportunities for face-to-face communication with the police in the jurisdiction for ordinary citizens. Grass-roots police stations specifically correspond with ordinary citizens, therefore, in terms of specific teaching and cooperation, the front-line policemen of the police stations in the district should be the main force of explaining and communicating. This working mechanism not only reduces the work of police stations, but also closes the distance among grassroots police. 


\section{F. Pay Attention to the Follow-up Organization of Citizen Police Academy Students}

Citizen police academy students are a new force in community policing. Paying attention to the follow-up organization of the students can maximize their role. In Western countries, in order to give full play to citizen police academy students, under the guidance and supervision of local police stations, Citizen Police Academy Alumni Association are established, and all graduates of citizen police academies can apply to join the association. Every month or two (vary in different places), a CPA alumni gathering is convened at police station for lectures, activities and outings. CPA alumni also have the opportunity to participate in a series of activities of police station, such as crime prevention guerrillas, phone investigations and other work of assisting in law enforcement and maintaining peace, so as to play an active role of police academy students.

\section{CONCLUSION}

On the basis of reference to the beneficial experience of the West, China can consider taking the following methods for the follow-up organization of citizen police academy students: the first is to establish WeChat group and QQ group of citizen police academy students. Through internal groups, public security organs can timely release some relevant police work dynamics, so that the students can constantly understand the local police work, strengthen the study of law enforcement knowledge, and timely know the requirements of police work. In addition, students can also reflect public security issues to public security organs through internal group and continue to serve public security organs and community. Secondly, corresponding association can be established under the guidance of public security organs. Various activities are held from to time to time through association, so as to strengthen the connection between students and local public security organs. In addition, it can also help citizen police academy association to actively set up websites, issue relevant publications, and enrich and expand the work carriers and methods of "citizen police academies".

\section{REFERENCES}

[1] Ma Wenhai. Analysis of Information Reform and Innovation Police Mechanism [J]. Policing Studies, 2009(2).

[2] Cui Haiying. CPAs from the Perspective of Community-oriented Police and Police Education in the United States [J]. Journal of Railway Police College, 2009, (3): 114.

[3] $\mathrm{Li}$ Wen, A New Interpretation of the Historical Development of the British Police System in Modern Times [J], Journal of Beijing People's Police College, 2010, (1)

[4] Shen Zhushi, Citizen Police Academies Recruit Students from "Weibo followers" [N], Wen Hui Bao, 2011-6-24.

[5] Li Zhongjian. On the Innovation of Policing Work Mechanism and the Improvement of Social Management Level [J]. Public Security Research, 2012 (3) .

[6] Ma Yongmei, Wu Yi: CPA: Cultivate Police Allies and Collaborators [N], China Public Daily, 2013-7-29.

[7] Tan Lingyan, Historical Origin, Development Achievements and Experience of American Citizen Police Academies [J], Journal of Yunnan Police Officer Academy, 2014, (2) .
[8] Ellen G, Cohn, The Citizen Police Academy: A Recipe for Improv ing Police- Community R elations, Journal of Criminal Justice, 1996(24):265- 271.

[9] Bonello, Elizabeth M, Schafer, Joseph A, Citizen Police Academies: Do They Just Entertain?, FBI Law Enforcement Bulletin, 2002, (11): 19- 23. 